\title{
Structural method speech training with video media to PKK women in Medan Polonia district
}

\author{
Nurhayati Harahap ${ }^{1 *}$, Dwi Widayati ${ }^{1}$, Ida Basaria ${ }^{1}$, Salliyanti ${ }^{1}$ \\ ${ }^{1}$ Fakultas Ilmu Budaya, Universitas Sumatera Utara, Medan \\ *Email: nurhayati1@usu.ac.id
}

\begin{abstract}
The Community Service Program is aimed at increasing the interest and speech ability of PKK women in Medan Polonia District and at the same time increasing reading interest, the ability to think logically and reasoning, the courage to express opinions, and to increase the creativity of PKK women in Medan Polonia District. The results of this training are: (1) Improving the ability of PKK mothers in giving public speeches. (2) Helps foster interest in reading PKK mothers for speech material. (3) Providing intensive speech training for PKK mothers. (4) Providing pocket books that can help PKK mothers understand good and correct speech methods and techniques. The results of this training have increased the insight of PKK mothers to give speeches properly and correctly in public and foster interest in reading because to search for speech topics requires insight into speech themes.
\end{abstract}

\section{Keywords: Training, Speech, Structured Method, Video Media, PKK Women}

\begin{abstract}
Abstrak
Program kegiatan Pengabdian Kepada Masyarakat ini bertujuan untuk meningkatan minat dan kemampuan berpidato Ibu-ibu PKK di Kecamatan Medan Polonia dan sekaligus meningkatkan minat baca, kemampuan berpikir logis dan bernalar, keberanian mengemukakan pendapat, serta peningkatan kreatifitas para Ibu-ibu PKK di Kecamatan Medan Polonia. Hasil dari pelatihan ini adalah: (1) Meningkatkan kemampuan ibu-ibu PKK dalam berpidato di muka umum. (2) Membantu menumbuhkan minat baca Ibu-ibu PKK untuk bahan berpidato. (3) Memberikan pelatihan berpidato secara intensif bagi ibuibu PKK. (4) Memberikan buku saku yangdapat membantu ibu-ibu PKK mengerti cara dan teknik berpidato yang baik dan benar. Hasil pelatihan ini telah menambah wawasan ibu-ibu PKK untuk berpidato dengan baik dan benar di muka umum serta menumbuhkan minat baca karena untuk mencari topik pidato dibutuhkan wawasan tentang tema pidato.
\end{abstract}

Kata Kunci: Pelatihan, Berpidato, Metode Terstruktur, Media Video, Ibu-Ibu PKK

\section{PENDAHULUAN}

Kecamatan Medan Polonia merupakan salah satu dari 21 kecamatan yang masuk kedalaman wilayah Kota Medan berdasarkan Peraturan Pemerintah Nomor. 22 Tahun 1973 padatanggal 10 Mei 1973, yang luasnya $\pm 3.025 \mathrm{Ha}$ dan terdiri dari 2 Kelurahan yang sebelumnya termasuk Kecamatan Medan Baru. Selanjutnya berdasarkan Keputusan Kepala Daerah Tk.I Sumatera Utara, tanggal 19 Oktober 1987 Nomor. 140/4078/K/1978 tentang Pemekaran Kelurahan di Wilayah Kota Medan, salah satu di antaranya terdapat di Kecamatan Medan Polonia maka, jumlah Kelurahan yang sebelumnya 2 Kelurahan menjadi 5 Kelurahan, yaitu Madras Hulu, Polonia, Sarirejo, Sukadamai, dan Anggrung. Kondisi fisik Kecamatan Medan Polonia secara geografis berada di wilayah tengah Kota Medan yang merupakan dataran kemiringan 0,5\%. Kecamatan Medan Polonia terdiri dari 5 (lima) kelurahan mempunyai batas-batas wilayah sebagai berikut:

1. Sebelah Utara berbatas dengan Kecamatan MedanPetisah;

2. Sebelah Selatan berbatasan dengan Kecamatan MedanJohor;

3. Sebelah Timur berbatasan dengan Kecamatan MedanMaimun;

4. Sebelah Barat berbatas dengan Kecamatan MedanBaru.

Berdasarkan informasi dari sekretaris PPK di Kecamatan Medan Polonia perlu diadakan pelatihan berpidato bagi ibu-ibu PKK. Berpidato adalah menyampaikan pidato, yaitu satu kegiatan berbicara di depan orang banyak. Pidato yang disampaikan secara lisan ini ada yang dengan cara serta merta 
(impromtu), menghafal, metode naskah, dan ekstemporer, atau dipersiapkan lebih dahulu. Metode atau cara apa pun yang dipakai, berpidato adalah penyampaian gagasan, ide, keinginan, cita-cita, bahkan khayalan seseorang kepada orang lain

(audiens) secara lisan (dalam Santosa:2015). Ibu-ibu PKK, yang merupakan singkatan Program Kesejahteraan Keluarga, adalah para pendamping, bahkan mitra pemerintah dalam melaksanakan tugastugas pemerintahan. Anggota PKK terdiri atas masyarakat dari berbagai unsur dan lapisan dengan diketuai oleh istri camat. Keberadaan dan peranan mereka sangat diharapkan dalam menyukseskan keberhasilan pelaksanaan pembangunan sesuai dengan program pemerintah. Dalam setiap unit pemerintahan di Indonesia, mulai dari desa, kelurahan, kecamatan, kabupaten, provinsi, sampai negara ada PKK. Adanya PKK di setiap unit pemerintahan tersebut mengindikasikan betapa pentingnya peranan Ibu-ibu PKK sebagai pendamping atau mitra pemerintah dalam memberhasilkan pembangunan. Anggota Ibu-ibu PKK adalah perempuan, yang umumnya para ibu rumah tangga. Dari segi pemberdayaan perempuan, pemerintah sekarang ini sangat merasa perlu meningkatkan kemampuan para ibu rumah tangga agar lebih berwawasan luas. Hal ini sejalan dengan perkembangan zaman bahwa ibu rumah tangga tidak hanya diharapkan mengurus rumah dan keluarga, tetapi juga menjadi

bagian masyarakat yang diharapkan berpartisipasi mengisi pembangunan. Untuk dapat berperan mengisi pembangunan, para Ibu PKK perlu dibekali berbagai keterampilan. Salah satunya adalah keterampilan berpidato. Oleh karena itu, perlu diasah keterampilan berpidato Ibu-ibu PKK agar pada masa yang akan dating adalah Ibu-ibu PKK yang tangguh dan piawai mengemukakan gagasannya dengan cara yang santun danberetika. Perlunya keterampilan berpidato ini bagi Ibu-ibu PKK sejalan dengan tugasnya yang disamping sebagi motivator agar masyarakat desa peduli dan tanggap terhadap program- program pemerintah, juga berfungsi sebagai public relation atau humas. Hal ini dibuktikan dengan seringnya Ibu-ibu PKK diundang

dan disertakan dalam kegiatan-kegiatan program pemerintah, baik yang dilaksanakan oleh lingkungan desa maupun unit pemerintahan yang lebih tinggi, seperti kecamatan, dan seterusnya. Misalnya ketika bupati bahkan presiden berkunjung desa-desa, para Ibu PKK adalah komponen yang selalu disertakan. Berpidato sebagai satu keterampilan berbicara memerlukan keterampilan tertentu. Oleh karena itu, tidak semua orang, dalam hal ini Ibu-ibu PKK, dapat berpidato, apalagi berpidato dengan kategori baik. Untuk dapat berpidato dengan

baik, mutlak diperlukan latihan, yang tidak cukup hanya sekali, akan tetapi berkali-kali. Latihan terutama dimaksudkan untuk mimik, nada bicara, intonasi, dan waktu. Oleh karena itu, sangat diperlukan pelatihan berpidato, terutama bagi Ibu-ibu PKK (lihat Burhan dalam Nuriman dan Ernais, 2017:490). Kemahiran berpidato didukung oleh beberapa hal, salah satunyaadalah bahan atau materi yang akan disampaikan dalam berpidato. Oleh karena itu, sebelum berpidato, seorang yang akan berpidato perlu mengumpulkan bahan informasi yang berhubungan dengan isi pidatonya tersebut. Kegiatan pengumpulan bahan pidato ini dengan sendirinya akan membuat para Ibu PKK menggali berbagai informasi dari berbagai sumber. Penggalian informasi ini tentu saja akan mencerdaskan sekaligus membuat Ibu-ibu PKK akan lebih kreatif. setelah bahan terkumpul, pekerjaan selanjutnya adalah membuat garis-garis besar

pidato. Selanjutnya, menguraikannya secara detail. Pembuatan garis-garis besar pidatodanmenguraikannya secara detail ini akan membuat ibu-ibu PKK berfikir kreatif, sistematis, dan logis, serta bernalar. Kebiasaan berfikir kreatif, sistematis, dan logis, serta bernalar ini akan mencerdaskan Ibu-ibu PKK. Dari uraian di atas, dapat dilihat betapa besarnya manfaat pelatihan berpidato bagi Ibu-ibu PKK. Satu hal yang sangat penting, pelatihan berpidato bagi Ibu-ibu PKK ini akan meningkatkan kualitas SDM Ibu-ibu PKK yang di tingkat pedesaan yang relatif rendah.

Berdasarkan situasi tersebut, tim staf pengajar Sastra Indonesia FIB USU bekerja sama dengan mitra, yaitu ketua TP. PKK Kecamatan Medan Polonia untuk memberi pelatihan berpidato kepada ibuibu PKK di Kecamatan Medan Polonia. Dengan diadakannya pelatian ini, diharapkan dapat membantu ibu-ibu PKK untuk tampil di muka umum dan dapat menyampaian pendapatnya secara baik dan benar.

\section{METODE PELAKSANAAN}


Metode pidato merupakan metode pembelajaran dalam pelaksanaan kegiatan pembelajaran berbicara arena di dalamnya terdapat kegiatan yang dilakukan dengan menggunakan kegiatan berbicara. Menurut Abidin (dalam Nuriman dan Ernais:2017), metode pidato terstruktur pada dasarnya merupakan metode pembelajaran berbicara yang menuntut terampil menulis sebuah gagasan secara baik dan terampil menyampaikan gagasan tersebut di hadapan orang banyak. Oleh sebab itu, metode ini sebenarnya bertujuan agar pembelajar pidato terampil berpidato secara utuh, baik dalam hal performa maupun penyusunan naskahnya. Tahapan aktivitas pembelajaran metode pidato terstruktur ini adalah sebagai berikut:

1. Tahap prabahasa lisan

Melakukan eksplorasi untuk menentukan gagasan pokok yang akan dikembangkan menjadi naskah pidato. Ibu-ibu PKK menyusun satuan gagasan dalam bentuk peta konsep yangberfungsi sebagai kerangka dasar naskah pidato yang akan disusunnya.

a. Menyusun naskah pidato.

b. Berlatih pidato.

2. Tahap berbahasa lisan

Pada tahap ini,peserta secara individu menyampaikan gagasannya dengan baik melalui kegiatan ceramah ataupun pidato.

3. Tahap pascaberbahasa lisan

Tanya jawab pada tahap ini, peserta bertanya jawab dengan peserta yang telah berpidato khususnya dalam hal isi gagasan disampaikanpembicara. Diskusi performa pada tahap ini, peserta dan pelatih mendiskusikan segala sesuatu yang berhubungan dengan halberpidato. Tindak lanjut pada tahap ini, peserta diberikan tugas untuk menyusun kembali naskah pidato dengan tema yang lain dan dilakukanpenilaian. Dalam pelatihan ini, dilakukan beberapa kali tahapan latihan berpidato. Peserta pelatihan terdiri atas utusan dari lima kelurahan, yaitu lima orang per kelurahan, sehingga jumlah peserta ada dua puluh lima orang. Berikut tahap yang dilakukan dalam pelatihan berpidato di Kecamatan MedanPolonia.

1. Kunjungan pertama, pada sesi pagi, ada dua hal yangdisampaikan: Menumbuhkan minat Ibuibu PKK untuk mengikuti pelatihan berpidato dengan semangat, yaitu dengan menyampaikan kelebihan-kelebihan dan keunggulan keunggulan yang dimiliki oleh seorang yang piawai berpidato dengan mencontohkan para tokoh-tokoh yang dikenal karena pidatonya serta pentingnya pelatihan untuk dapat berpidato denganbaik.

2. Teknik berpidato, yaitu menyampaikan hal-hal yang perlu diperhatikan dalam berpidato, yaitu:

a. mempelajari pendengar,

b. cara-cara mengorganisasikan dan menyusun pidato yang baik sehingga dapat menyampaikan pidato dengan baik dan tertib, dan

c. cara membuka pidato yang menarik dan membangkitkan minat pendengar serta menutup pidato sehingga dapat meninggalkan kesan yang mendalam pada pendengar atas pidato yang disampaikan. Selanjutnya diskusi, yaitu tanya jawab antara peserta dengan tim pelatih atas hal-hal yang tidak jelas bagi peserta diskusi tentang materi yang disampaikan.

Pada sesi ini juga ditampilkan video orator-orator yang sudahterkenal. Pada sesi siang, peserta pelatihan praktek menyusun naskah pidato. Pada sesi ini,peserta diminta menulis teks pidato berdasarkan hal-hal yang harus ada dalam teks pidato,yaitu:

1. Pembuka pidato,

2. isi pidato,

3. penutup pidato,dan

4. salam penutup.

Setelah peserta menulis pidato, pelatih memberikan umpan balik terhadap pidato yang disusun oleh peserta. Hal ini bertujuan untuk memberi masukan kepada peserta sehingga peserta paham cara menulis pidato yang baik dan benar. 
Kunjungan kedua, dibagi atas dua sesi, yaitu sesi pagi dan sesi siang. Pada sesi pagi, satu perwakilan dari setiap kelurahan secara diminta untuk berpidato di depan peserta pelatihan dan peserta lain mendengarkan dengan seksama. Pada sesi siang, video pidato kelima peserta ditampilkan di layar untuk dievaluasi. Berdasarkan hasil evaluasi, peserta lain dari setiap kelompok yang belum berpidato, diminta berpidato sejumlah lima peserta dari perwakilan tiap-tiap kelurahan. Setelah peserta tampil, pelatih memberikan umpan balik kepada peserta terkait penyampaian pidatotersebut. Kunjungan ketiga, juga dibagi atas dua sesi, yaitu sesi pagi dan sesi siang. Pada sesi pagi, dua perwakilan dari setiap kelurahan diminta untuk berpidato di depan peserta pelatihan. Pada sesi siang, peserta pelatihan diminta untuk mengevaluasi tiga orang peserta yang dianggap baik untuk dijadikan sebagai model atau contoh.Selanjutnya,masing-masing satu peserta yang belum melakukan praktek pidato diminta berpidato dengan mengadaptasi hal-hal baik yang dipelajari dari penayangan video berpidato peserta sebelumnya. Video pidato kelima peserta tersebut ditampilkan di layar untuk dievaluasi. Berdasarkan hasil evaluasi, peserta lain dari setiap kelompok yang belum berpidato, diminta berpidato. Setelah semua peserta tampil, pelatih memberikan umpan balik. Semua pidato yang ditampilkan hari ini diberi masukan.

\section{HASIL DAN PEMBAHASAN}

\subsection{Hasil Kegiatan}

Hasil dari pelatihan ini adalah: (1) Meningkatkankemampuan ibu-ibu PKK dalam berpidato di muka umum. (2) Membantu menumbuhkan minat baca Ibu-ibu PKK untu bahan berpidato. (3) Memberikan pelatihan berpidato secara intensif bagi ibu-ibuPKK. (4)Memberikan buku saku yangdapat membantu ibu-ibu PKK mengerti cara dan teknik berpidato yang baik dan benar.

\subsection{Pembahasan}

Sesuai dengan judul yang diuraikan dalam proposal, sasaran pelatihan berpidato pada pengabdian ini adalah Ibu-ibu PKK di Kecamatan Medan Polonia, Provinsi Sumatera Utara. Kegiatan pelatihan dilaksanakan di ruangan aula kantor camat Medan Polonia, Jalan De Barito, Kecamatan Medan Polonia. Pesertanya adalah ibu-ibu PPK dari enam kelurahan di Kecamatan Medan Polonia. Setiap kelurahan mengutus empat orang ibu PKK untuk mengikuti pelatihan pidato. Keseluruhan peserta berjumlah tiga puluh orang. Pelatihan dilakukan dengan menyampaikan materi tentang pidato dan cara-cara berpidato diikuti dengan pemutaran video berpidato.

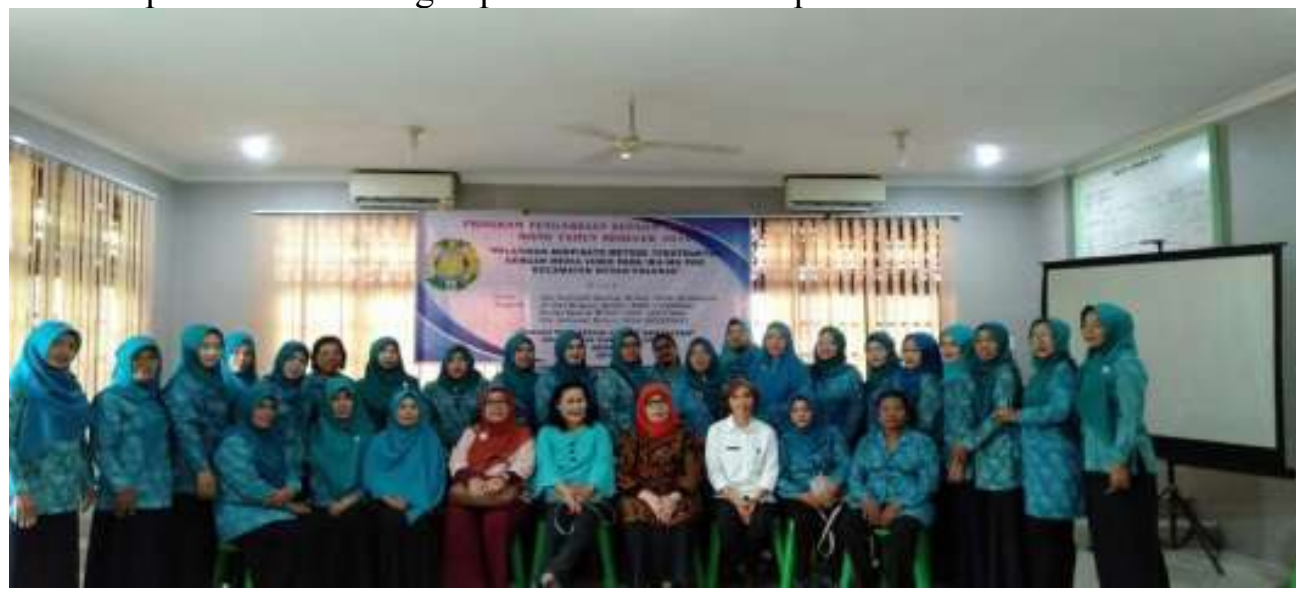

Gambar 1. Foto bersama ibu-ibu PKK Kecamatan Medan Polonia 


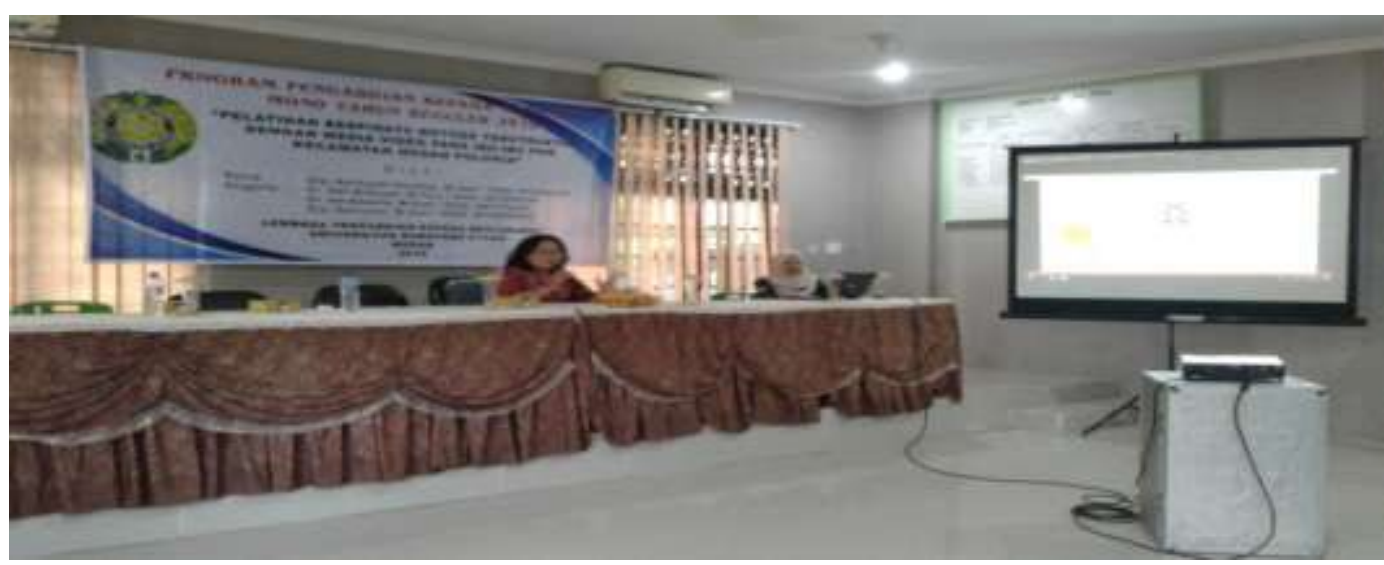

Gambar 2. Pemberian materi berpidato

Setelah pemutaran video pidato, terjadi tanya jawab antara penyuluh dengan peserta pelatihan. Kemudian, para peserta dibagi menjadi empat kelompok. Setiap kelompok diminta menulis pidato sesuai tema yang telah dipilih dan perwakilan dari peserta diminta tampil serta diberi umpan balik oleh panitia pelatihan.

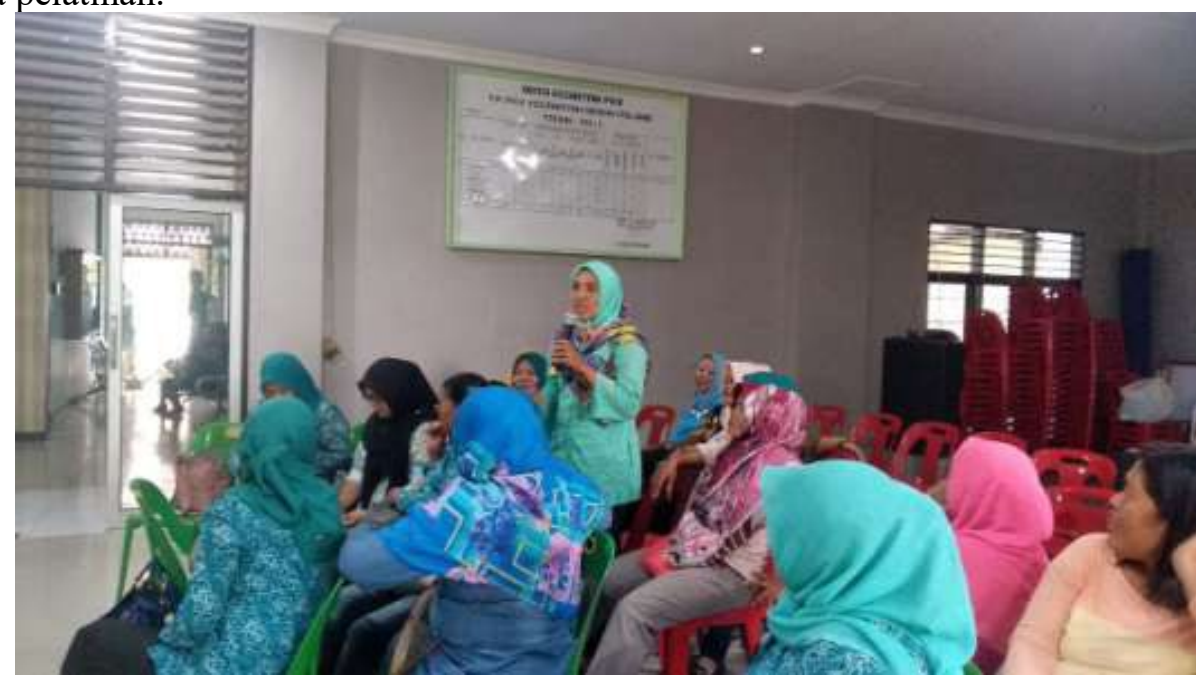

Gambar 3. Ibu PKK memberi pertanyaan kepada pemateri 


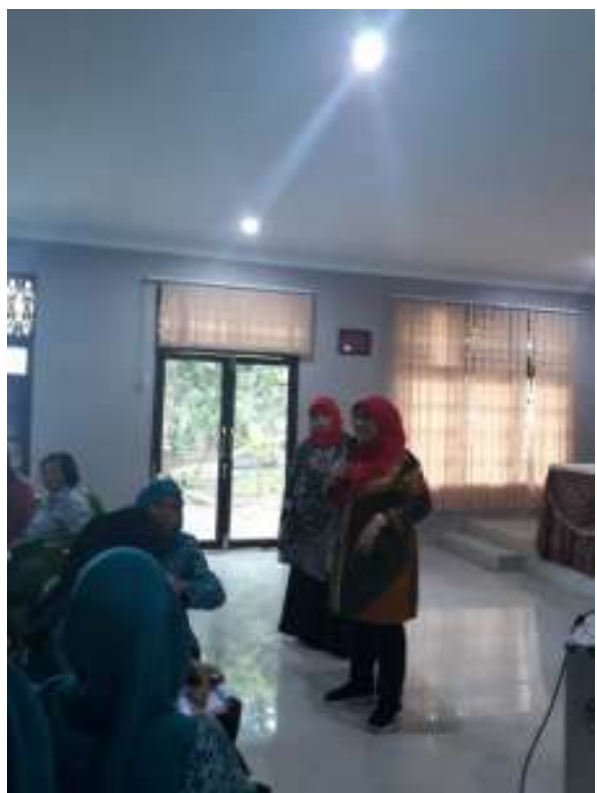

Gambar 4. Pembentukan kelompok ibu-ibu PKK

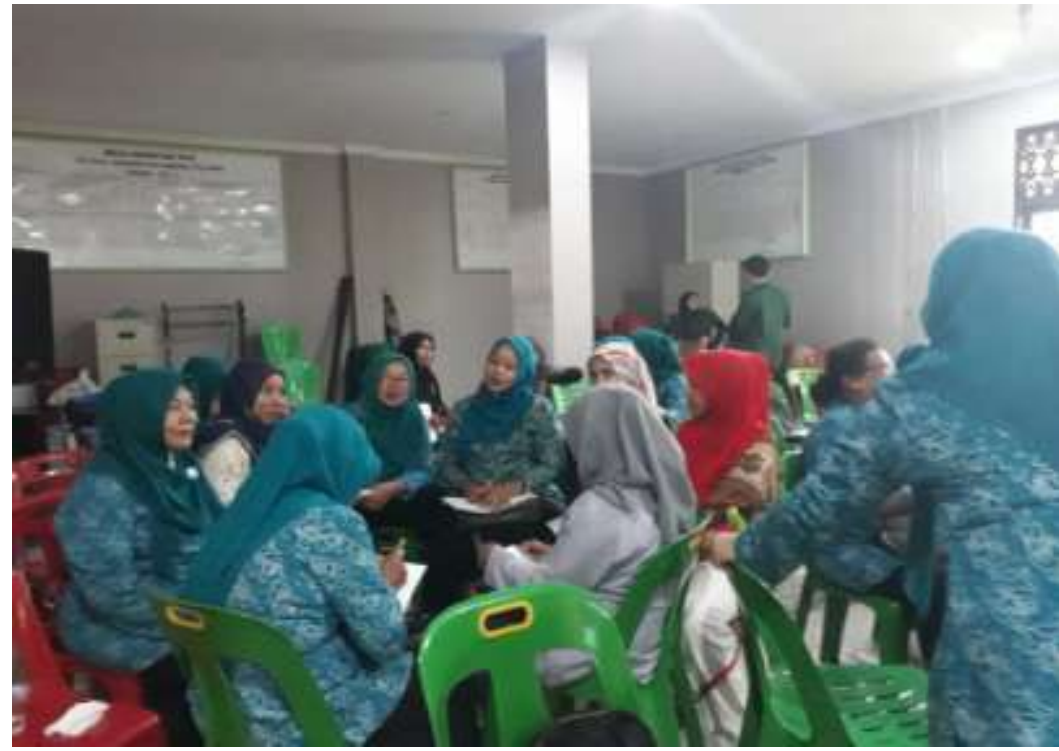

Gambar 5. Diskusi penentuan tema dan kerangka pidato 


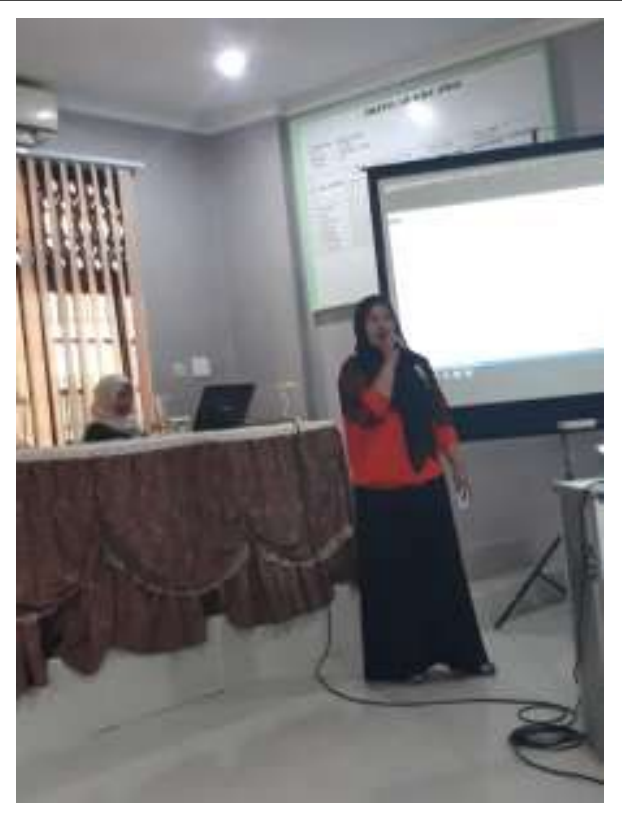

Gambar 6. Penampilan pidato oleh ibu PKK

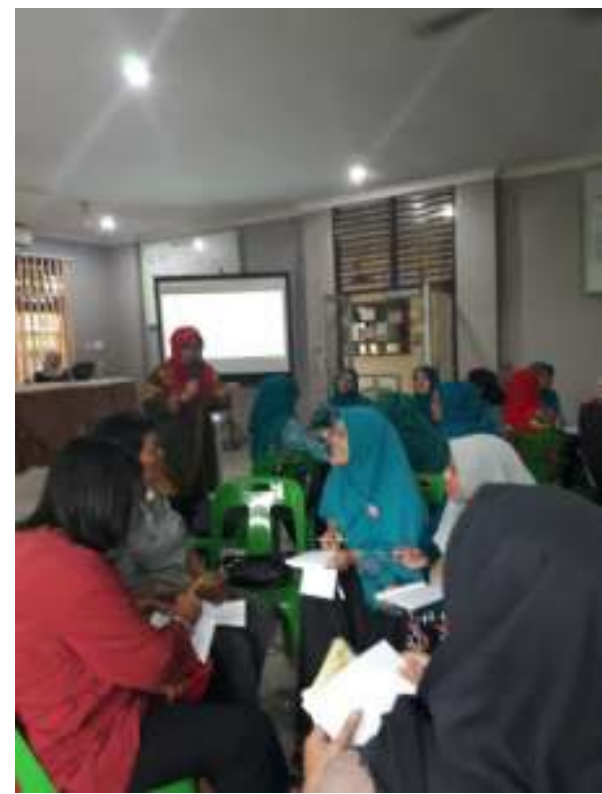

Gambar 7. Umpan balik dari panitia pelatihan

Pada hari kedua, peserta diminta tampil untuk berpidato di hadapan panitia pelatihan dan peserta lain. Kegiatan ini disimpan dalam bentuk video. Video pidato tersebut diputar kembali dan peserta lain diminta untuk memberi umpan balik terhadap pidato tersebut. 
Nurhayati Harahap et.al. Structural method speech training with video media to PKK women

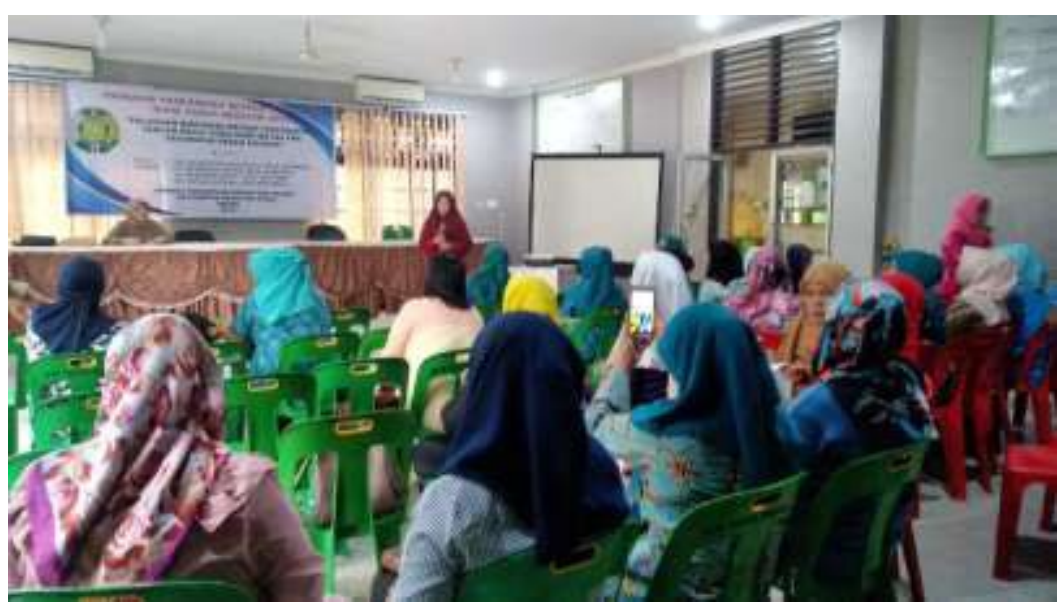

Gambar 8. Penampilan pidato ibu PKK di hari kedua

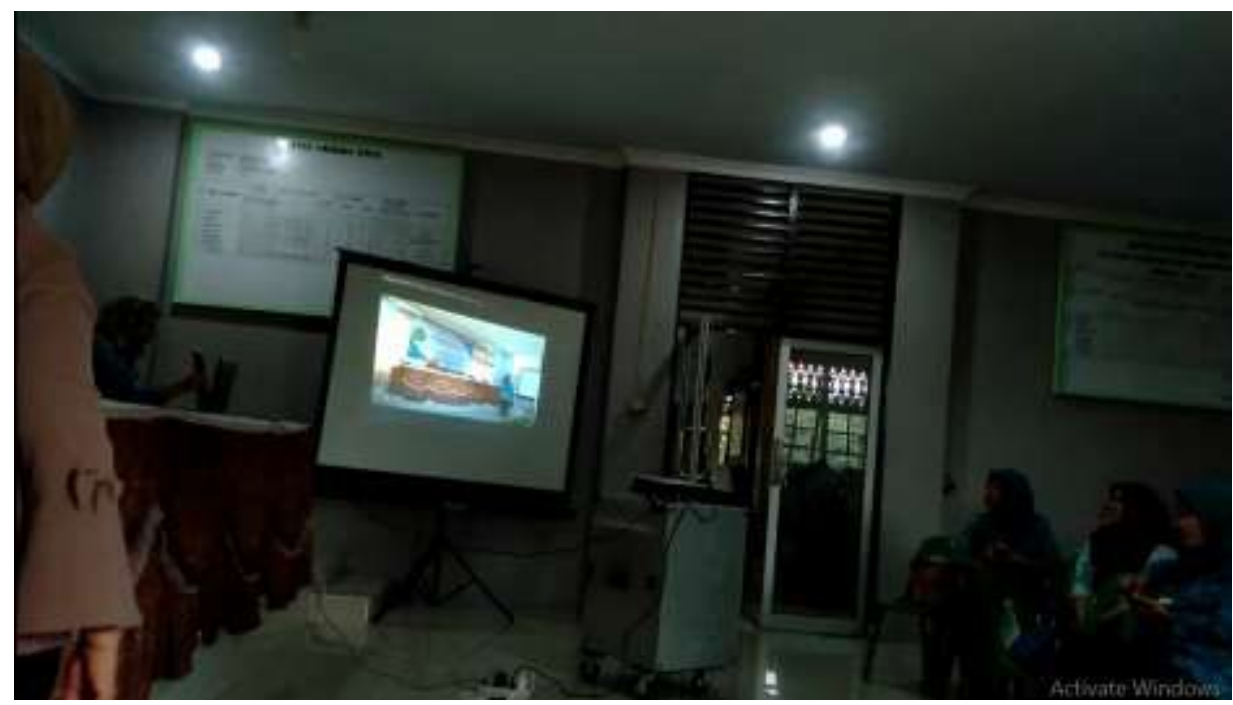

Gambar 9. Pemutaran video pidato ibu PKK di hari kedua

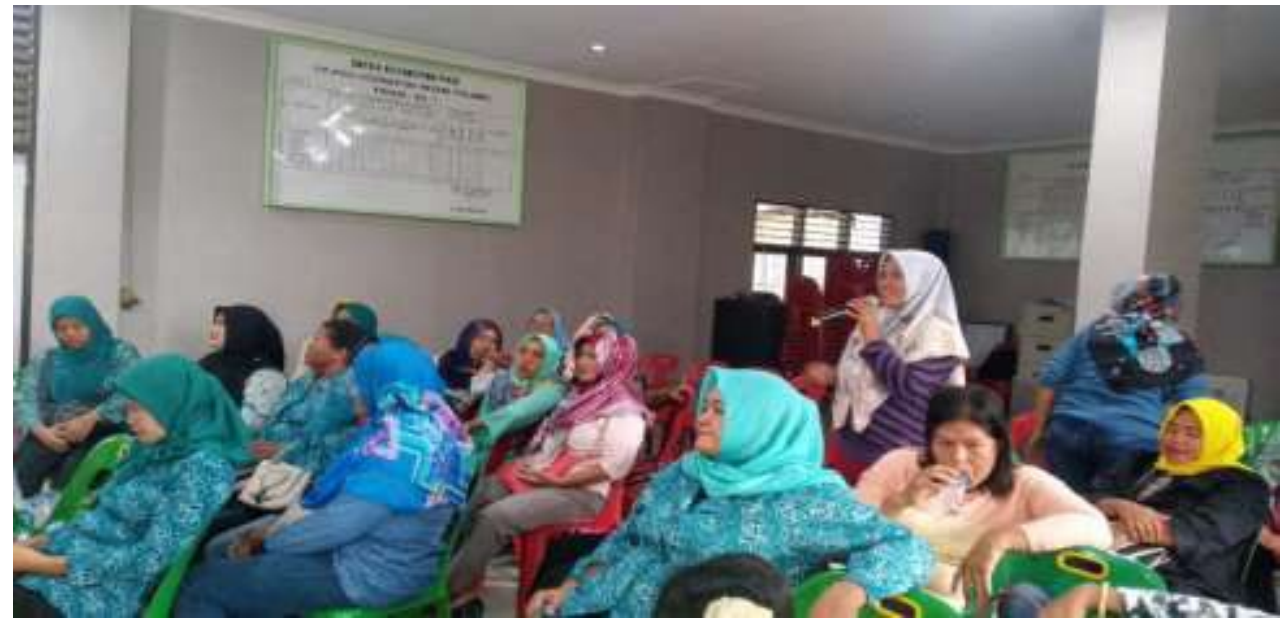

Gambar 10. Penyampaian umpan balik oleh peserta pidato ibu PKK di hari kedua 


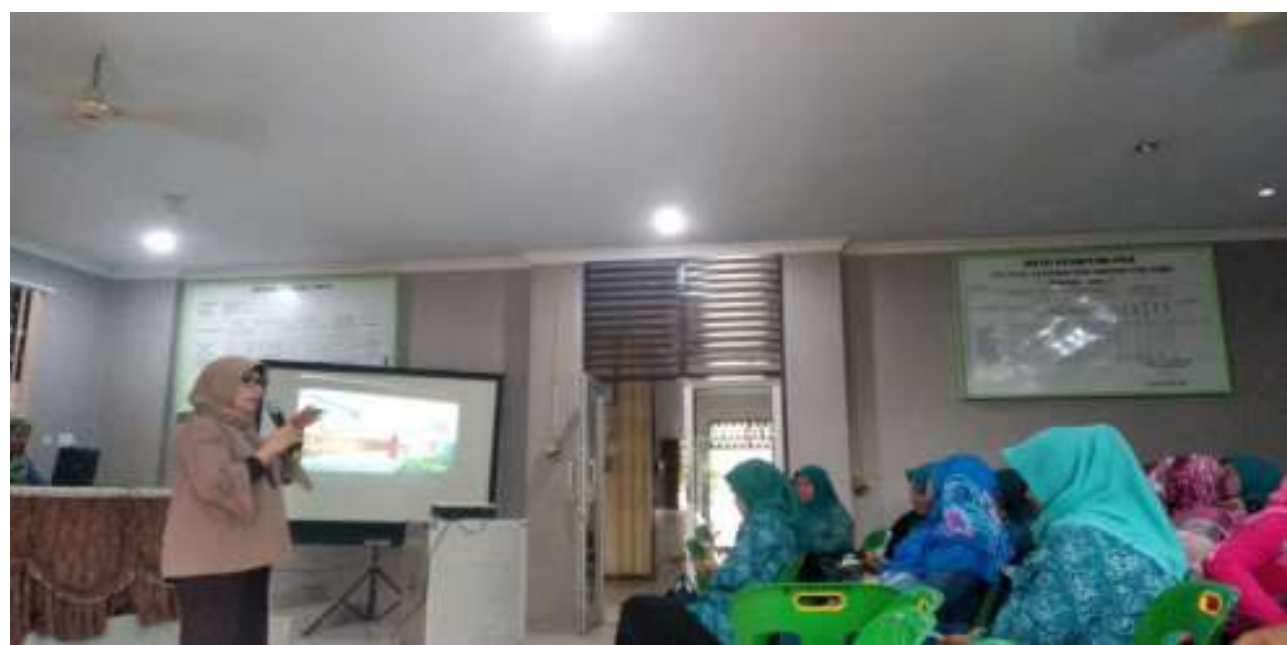

Gambar 11. Penyampaian umpan balik oleh pelatih pidato ibu PKK di hari kedua

Pada pertemuan berikutnya, ibu-ibu PKK Kecamatan Medan Polonia memberikan penampilan terbaik dengan menari di hadapan panitia dan para peserta pelatihan sebagai persembahan untuk panitia pelatihan pidato yang membantu memahami cara berpidato yang baik dan benar. Setelah penampilan tersebut, diadakan perlombaan berpidato dan dipilih juara terbaik dalam perlombaan tersebut. Peserta yang menang mendapat bingkisan. Dengan berakhirnya perlombaan berpidato tersebut, maka berakhir pulalah pelatihan pidato metode terstruktur dengan media video ibu-ibu PKK di kecamatan Medan Polonia.

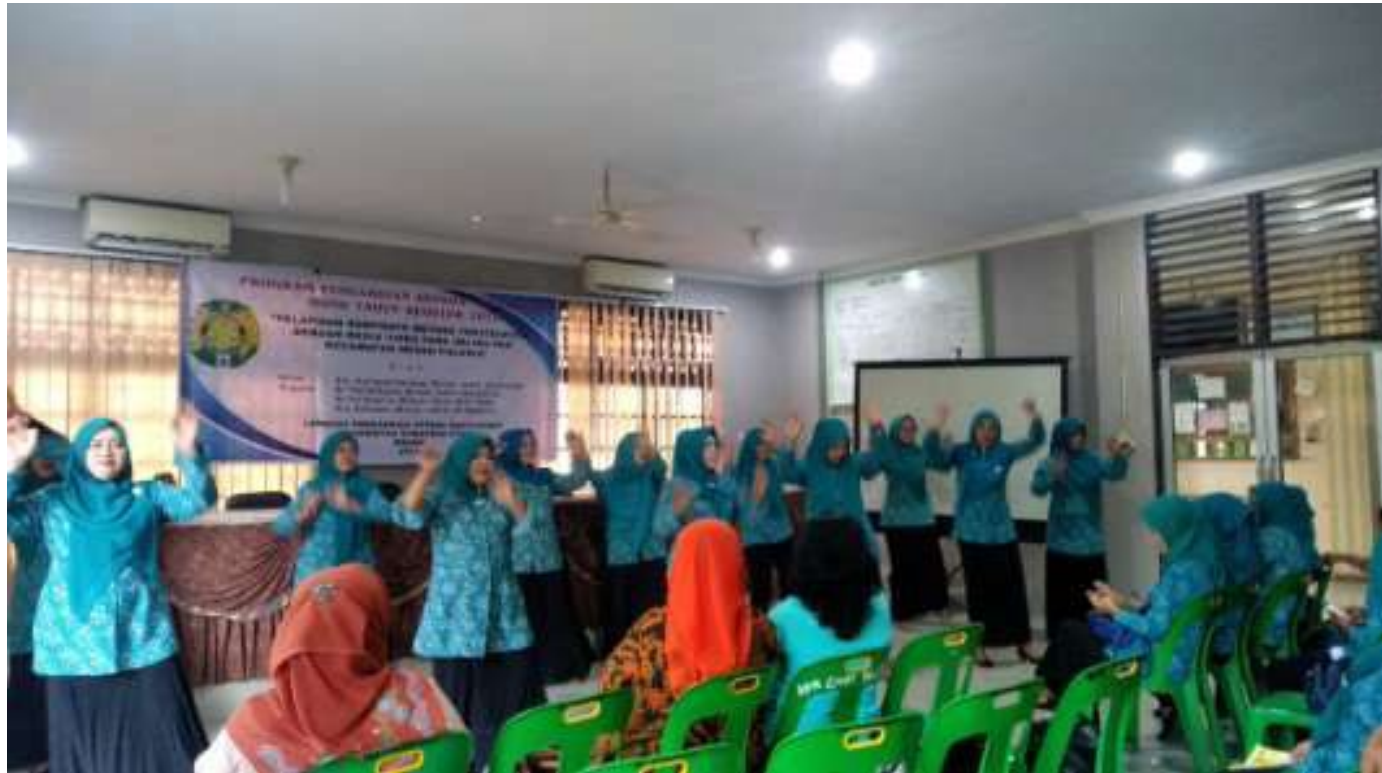

Gambar 12. Persembahan tari oleh ibu-ibu PKK peserta pidato 

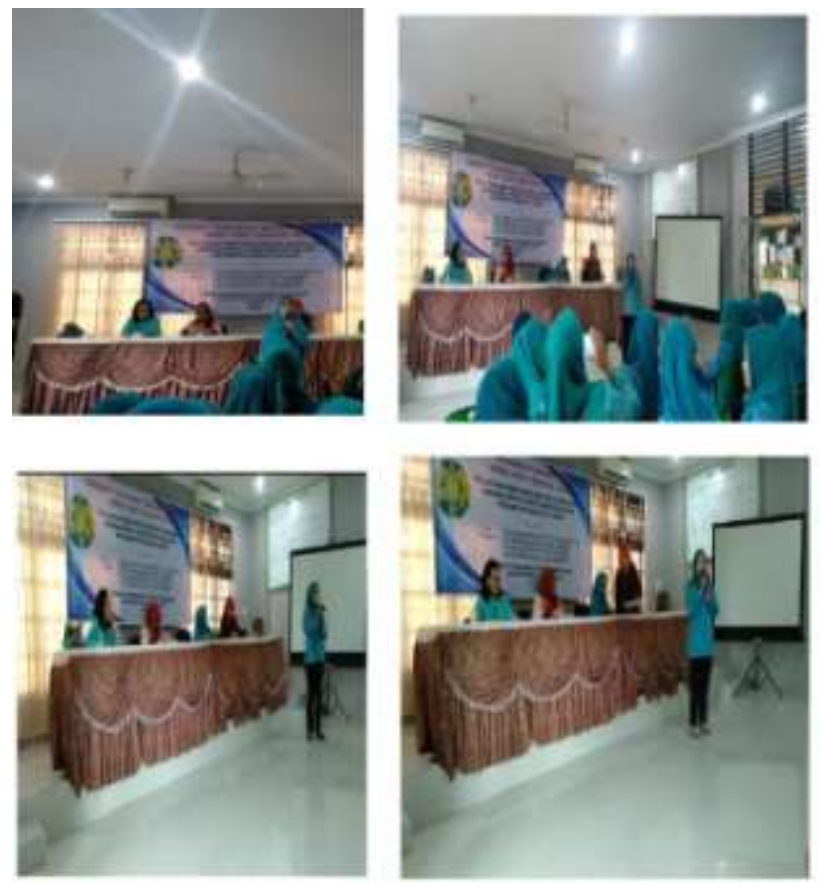

Gambar 13. Penampilan lomba pidato ibu-ibu PKK

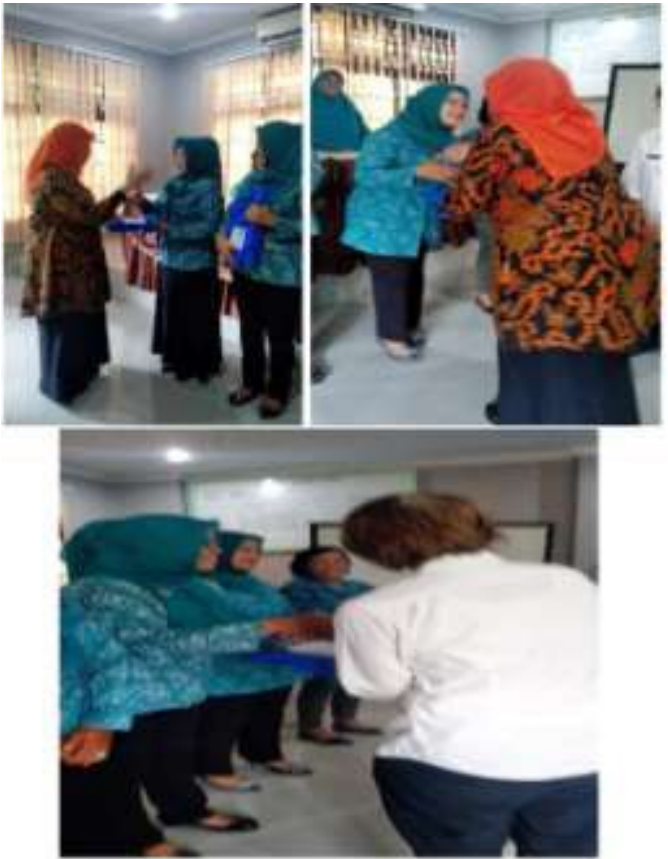

Gambar 14. Penyerahan bingkisan kepada ibu-ibu PKK pemenang lomba pidato

Hasil pelatihan ini telah menambah wawasan ibu-ibu PKK untuk berpidato dengan baik dan benar di muka umum serta menumbuhkan minat baca karena untuk mencari topik pidato dibutuhkan wawasan tentang tema pidato tersebut. Hal ini nampak dari begitu bersemangatnya ibu-ibu PKK kecamatan Medan Polonia ketika berdiskusi dengan kelompoknya dalam pembuatan pidato. Demikian juga ketika diminta untuk berpidato di muka umum semua peserta menyimak dan sangat antusias.Ketika melihat pemutaran video berpidato banyak peserta yang

aktif memberikan umpan balik dan masukan kepada peserta yang berpidato dalam video tersebut. Semua peserta juga menyimak umpan balik yang disampaikan oleh penyuluh pelatihan. Pada 
perlombaan pidato di hari terakhir, juara I berpidato dengan sangat memukau dan menarik perhatian peserta dan panitia pelatihan. Hal ini menunjukkan bahwa pelatihan berpidato ibu-ibu PKK metode terstruktur dengan media video di Kecamatan Medan Polonia berjalan lancar dan baik. Pelatihan berpidato ini berdampak positif bagi ibu-ibu PKK kecamatan Medan Polonia. Adapun hasil yang diperoleh dari pelatihan berpidato ini adalah:

1. Meningkatkan kemampuan ibu-ibu PKK dalam berpidato di muka umum.

2. Membantu menumbuhkan minat baca Ibu-ibu PKK untuk bahan berpidato.

3. Memberikan pelatihan berpidato secara intensif bagi ibu-ibuPKK.

4. Memberikan buku saku yangdapat membantu ibu-ibu PKK mengerti cara

dan teknik berpidato yang baik dan benar. Hasil pelatihan ini telah menambah wawasan ibu-ibu PKK untuk berpidato dengan baik dan benar di muka umum serta menumbuhkan minat baca karena untuk mencari topik pidato dibutuhkan wawasan tentang tema pidato tersebut. Hal

ini nampak dari begitu bersemangatnya ibu-ibu PKK kecamatan Medan Polonia etika berdiskusi dengan kelompoknya dalam pembuatan pidato. Demikian juga ketika diminta untuk berpidato di muka umum semua peserta menyimak dan sangat antusias.Ketika melihat pemutaran video berpidato banyak peserta yang aktif memberikan umpan balik dan masukan kepada peserta yang berpidato dalam video tersebut. Semua peserta juga menyimak umpan balik yang disampaikan oleh penyuluh pelatihan. Pada perlombaan pidato di hari terakhir, juara I berpidato dengan sangat memukau dan menarik perhatian peserta dan panitia pelatihan. Hal

ini menunjukkan bahwa pelatihan berpidato ibu-ibu PKK metode terstruktur dengan media video di Kecamatan Medan Polonia berjalan lancar dan baik. Pelatihan berpidato ini berdampak positif bagi ibuibu PKK kecamatan Medan Polonia. Adapun hasil yang diperoleh dari pelatihan berpidato ini adalah:

1. Meningkatkan kemampuan ibu-ibu PKK dalam berpidato di muka umum.

2. Membantu menumbuhkan minat baca Ibu-ibu PKK untuk bahan berpidato.

3. Memberikan pelatihan berpidato secara intensif bagi ibu-ibuPKK.

4. Memberikan buku saku yangdapat membantu ibu-ibu PKK mengerti cara dan teknik berpidato yang baik dan benar.

\section{KESIMPULAN}

Dari kegiatan pelatihan ini panitia pelatihan dapat menyimpulkan bahwa kegiatan berpidato sangat berdampak positif untuk ibu-ibu PKK. Pada awal pertemuan, ketika panitia pelatihan menyampaikan akan mengadakan pelatihan berpidato, ibu-ibu PKK yang menjadi sasaran pelatihan sangat antusias karena merasa pentingnya pelatihan tersebut. Demikian juga ketika ditayangkan contoh berpidato dengan media video, ibu-ibu PKK sangat antusias. Jadi, ibu-ibu PKK aktif dalam pelatihan berpidato. Ketika tim pelatihan usai penyajian materi tentang pidato, ibu-ibu PKK sangat antusias bertanya. Bahkan harus dibatasi karena perkiraan waktu. Demikian juga ketika para pelatih memandu untuk pembagian kelompok, seluruh peserta merasa bersemangat. Lebih menggembirakan lagi ketika peserta diminta berpidato, peserta tampil dengan baik. Juga ketika diumpan balik, peserta menyimak dan mencatat masukan tersebut.

Ketika diminta lagi berpidato, peserta berpidato degan cara yang lebih baik dari sebelumnya. Hal ini membuktikan bahwa pelatihan ini sangat berarti bagi ibu-ibu PKK. Berpidato yang baik tadinya tidak begitu mereka kuasai dan tidak terlalu menjadi hal yang penting, dengan pelatihan ini menjadi menarik. Pelatihan ini menumbuhkan minat baca ibu-ibu PKK menjadi lebih baik. Demikian kemampuan mereka berpidato menjadi lebih baik. Selain itu, pelatihan ini juga meningkatkan wawasan mereka untuk menyampaikan gagasan di muka. 


\section{UCAPAN TERIMAKASIH}

Ucapan terima kasih kami sampaikan kepada Ketua Lembaga Pengabdian pada Masyarakat Universitas Sumatera Utara, Dekan Fakultas Ilmu Budaya, Staf dosen Program Studi Sastra Indonesia, mitra kami, yaitu Camat Medan Polonia dan Staff Administrasi, dan Ketua PKK serta Sekretari PKK yang telah membantu kami dalam menyelesaikan kegiatan pengabdian masyarakat ini.

\section{DAFTAR PUSTAKA}

Camat Medan Polonia. 2018. Laporan Kependudukan 2018.Tidak Diterbitkan.

Nuriman, Lukman dan Ernalis. 2017. "Penggunaan Metode Pidato Terstruktur untuk Meningkatkan Kemampuan Berbicara”. Jurnal Antologi UPI, Vol. 5, No. 1, Agustus 2017.

Santosa, Jaka. 2015. "Pembelajaran Menulis Teks Pidato Dan Berpidato Kelas X Di Sma Negeri 3

Sukoharjo". Jurnal Penelitian Humaniora, Vol. 16, No. 1, Februari 2015.

Yeti Mulyati, dkk. 2007. Keterampilan Berbahasa Indonesia SD. Jakarta: Universitas Terbuka. 